\title{
Fructans and antioxidants in leaves of culinary herbs from Asteraceae and Amaryllidaceae families
}

\author{
*Petkova, N.Tr., Ivanov, I.G., Raeva, M., Topuzova, M.G., Todorova, M.M. and Denev P.P. \\ University of Food Technologies, Technological Faculty, Department of Organic Chemistry and Inorganic \\ Chemistry, 26 Maritza Blvd., 4002, Plovdiv, Bulgaria
}

\begin{abstract}
Article history:
Received: 2 February 2019

Received in revised form: 23

February 2019

Accepted: 24 February 2019

Available Online: 10 March 2019
\end{abstract}

\section{Keywords:}

Culinary herbs,

Carotenoids,

Fructans,

Inulin,

Total phenols,

Antioxidants

\section{DOI:}

https://doi.org/10.26656/fr.2017.3(5).030

\begin{abstract}
Culinary herbs were known and applied from ancient times in food production and for culinary purposes, as flavor enhancers and food preservation, because of the bioactive substances with antimicrobial and antioxidant properties. Therefore, they can successfully use as sources of natural antioxidants that improve consumer health and the nutritional value of foodstuffs. The aim of the current study was to evaluate the fructan content and antioxidant activity in leaves of four culinary herbs: tarragon (Artemisia dracunculos L.), chives (Allium schoenoprasum L.), wild garlic or ramson (Allium ursinum L.) and samardala (Nectaroscordum siculum Lindl.) used in Bulgarian traditional cuisine. The content of total chlorophylls, total carotenoids, phenols, derivatives of caffeic acids (DCA), flavonoids and fructans in culinary herb extracts were analysed. The antioxidant activity of the water extracts was evaluated by two reliable methods (DPPH and FRAP). It was found that chives dry leaves contained the highest total chlorophylls $(2255 \mu \mathrm{g} / \mathrm{g} \mathrm{dw})$. Total carotenoids and DCA were detected only in tarragon leaves, where, in addition, the total phenol content was the highest ( $25 \mathrm{mg} \mathrm{GAE} / \mathrm{g} \mathrm{dw}$ ). It possessed the highest antioxidant potential probably due to the high polyphenolic content. However, the leaves of samardala showed the highest total flavonoids content (7.87 mg QE/ g dw), while chives possessed the highest total fructans $(5.66 \mathrm{~g} / 100 \mathrm{~g} \mathrm{dw})$. This is the first report that evaluated chives, wild garlic and tarragon leaves as natural sources of prebiotics from fructan family, especially 1-kestose found in them. The current study demonstrated the antioxidant potential and prebiotics content in four culinary herbs used as spices in nutritional habitats of Bulgarian consumers.
\end{abstract}

\section{Introduction}

Nowadays medicinal plants attract consumer's attention as a natural source of antioxidants (Petkova et al., 2017). Many of them are used in culinary practice for flavoring dishes and as antibacterial agents during food preservation. According to European Spice Association, culinary herbs and spices are the edible parts of plants that are traditionally added to foodstuffs for either their natural flavoring, aromatic and/or visual properties (ESA, 2018). Consumer information is a very important decision-making factor when purchasing, but there are not always, on the packaging.

Among the great variety of spices consumed and used in food processing except for savory, attention deserves some representatives from Amaryllidaceae family, genus Allium, as chives (Allium schoenoprasum L.), ramson (Allium ursinum L.) and samardala (Nectaroscordum siculum Lindl.). Nevertheless, the genus Allium contains an estimated 750 species (Mathew, 1996) comprising onions, scallion, garlic, spring garlic, and leek are members of the Amaryllidaceae family (Jovanovic-Malinovska et al., 2014). Several of the species or varieties (as garlic, elephant garlic, onions, spring onions, shallots, leeks, welsh onions and chives) are well-known edible plants (Phillips and Rix, 1998). Some other representatives, as ramsons and crow garlic, are not usually cultivated, but wild growing, with minor culinary role. The detailed characteristics of culinary and medicinal application of the leaves from some culinary herbs were listed (Table 1).

Chives (Allium schoenoprasum L.) derive from the cold regions of Europe and Asia and it presents as a plant with slim, dark green leaves and pale purple flowers, used dried or in a frozen state. Drying procedure considerably reduces the characteristic aroma (Kmiecik and Lisiewska, 1999), while freezing often affects 
Table 1. Culinary and medicinal application of the leaves from investigated culinary herbs

\begin{tabular}{|c|c|c|c|}
\hline Common name & Family & Culinary purpose & Medicinal Uses \\
\hline $\begin{array}{c}\text { Chives } \\
\text { (Allium } \\
\text { schoenoprasum } \\
\text { L.) }\end{array}$ & Amaryllidaceae & $\begin{array}{l}\text { For culinary purposes as a flavoring } \\
\text { herb, to garnish dishes }\end{array}$ & $\begin{array}{l}\text { Stimulate digestion, treat anemia, to purify } \\
\text { the blood, mild stimulant, diuretic, } \\
\text { antiseptic properties, antioxidants, anti- } \\
\text { inflammatory and antihypertensive (Haro et } \\
\text { al., 2017). }\end{array}$ \\
\hline $\begin{array}{c}\text { Ramson } \\
\text { (Allium ursinum } \\
\text { L.) }\end{array}$ & Amaryllidaceae & $\begin{array}{l}\text { Raw, pickled, salted or in brine with } \\
\text { oil, in salads, soup, potatoes, cabbage, } \\
\text { stewed vegetables, meat dishes } \\
\text { (Piątkowska et al., 2015) or as an } \\
\text { ingredient in a sauce, a substitute for } \\
\text { pesto in lieu of basil. }\end{array}$ & $\begin{array}{l}\text { Antioxidant, hunger-provoking agent, for } \\
\text { intestinal problems, fungicidal and anti- } \\
\text { bacterial properties (Blazewicz-Wozniak } \\
\text { and Michowska, 2011; Tomšik et al., 2018) } \\
\text { gastrointestinal tract or skin infections } \\
\text { (Piątkowska et al., 2015) }\end{array}$ \\
\hline $\begin{array}{c}\text { Samardala } \\
\text { (Nectaroscordum } \\
\text { siculum Lindl.) }\end{array}$ & Amaryllidaceae & $\begin{array}{l}\text { As a spice, in salads, sandwiches, } \\
\text { roasted, fried, boiled potatoes, rice } \\
\text { dishes, fried eggs, boiled meat, lamb, } \\
\text { chicken, roasted mushrooms, } \\
\text { cucumbers and tomatoes. Combines } \\
\text { with cheese, spinach and nettle dishes. }\end{array}$ & $\begin{array}{l}\text { For hypertension, anti-inflammatory } \\
\text { properties help in various cardiovascular } \\
\text { diseases, cancer and atherosclerosis, } \\
\text { facilitates digestion and increases appetite. } \\
\text { Helps against psoriasis and cough. } \\
\text { Stimulates urination, cleanses the bladder } \\
\text { and kidneys (Popova et al., 2014a, 2014b) }\end{array}$ \\
\hline $\begin{array}{c}\text { Tarragon } \\
\text { (Artemisia } \\
\text { dracunculus L.) }\end{array}$ & Asteraceae & $\begin{array}{l}\text { Chicken, fish, rice, meat and egg } \\
\text { dishes. A flavouring component of } \\
\text { Béarnaise sauce, in salads, soups, } \\
\text { vegetables, pasta (Pripdeevech and } \\
\text { Wongpornchai, 2004) }\end{array}$ & $\begin{array}{l}\text { Facilitates breathing, strengthens sleep and } \\
\text { normalizes the acidity of gastric juice, } \\
\text { strengthens appetite, for diseases of the } \\
\text { blood and the cardiovascular system } \\
\text { (Obolskiy et al., 2011). }\end{array}$ \\
\hline
\end{tabular}

texture and color. Štajner et al. (2004) have found that leaves have the highest antioxidant activity in comparison with bulbs and stalks. The pharmacological effects are caused by flavoring compounds diallyl sulphides (diallyl monosulphide, diallyl disulphide, diallyl trisulphide, diallyl tetrasulphide), as well as polyphenolic compounds, vitamin $\mathrm{C}$ and carotenoids (Vlase et al., 2013).

Allium ursinum L. also known as ramsons, bear's garlic, wild garlic is a perennial plant growing on fertile soil in shady, humid places in Europe and in the northern hemisphere of Asia (Tomšik et al., 2018). The nutritional composition of leaves of wild garlic comprises dry matter $(79.0 \mathrm{~g} / \mathrm{kg})$, ash $(8.9 \mathrm{~g} / \mathrm{kg})$, proteins $(13.7 \mathrm{~g} / \mathrm{kg})$, crude fat $(5.6 \mathrm{~g} / \mathrm{kg})$, total carbohydrates $(50.8 \mathrm{~g} / \mathrm{kg})$, dietary fibres $(26.9 \mathrm{~g} / \mathrm{kg})$, vitamin C $(956.1 \mathrm{mg} / \mathrm{kg})$, and antioxidant activity $(25.0 \mathrm{mmol} \mathrm{TEAC} / \mathrm{kg})$, and minerals - K (34.6 g/kg), Mg (1.72 g/ $/ \mathrm{kg}), \mathrm{Fe}(230.3 \mathrm{mg} / \mathrm{kg})$ and Zn $(58.8 \mathrm{mg} / \mathrm{kg}$ ) (Piątkowska et al., 2015). Ramson leaves were sold on local markets: fresh, salted or dried as a spice.

Allium bulgaricum (Nectaroscordum siculum Lindl., Nectaroscordum siculum ssp. bulgaricum (Janka) Stearn; Allium ursium var. Dioscoridis) is a plant which belongs to Amaryllidaceae family, subfamily Allioideae, Allium species (Popova et al., 2014a). In Bulgaria it is known as samardala or 'Bulgarian honey garlic'. The plant is used for culinary purposes (Popova et al., 2014b). The antioxidant activity of aqueous extracts of dried leaves (Popova et al., 2014a), aqueous extracts of fresh leaves
(Alexieva et al., 2013) and water-ethanol extracts of fresh plant material of wild growing samardala (Popova et al., 2014b) were studied. It was shown that the waterethanol extracts of dried leaves of Allium bulgaricum L. demonstrated higher polyphenol content and higher antioxidant activity in comparison with the values obtained from extracts of Allium ursinum L. (Alexieva et al., 2014).

All the Allium species may help to prevent tumour promotion, cardiovascular diseases and aging due to their high concentrations of total flavonoids, carotenoids and chlorophylls, and very low concentrations of toxic oxygen radicals (Grzeszczuk et al., 2011). The most typical feature for all Allium species is the accumulation of high content of organosulfur substances, that during cooking decomposed to thiosulfinates, including diallyl, methyl allyl and diethyl mono-, di-, tri-, tetra-, pentaand hexasulfides, the vinyldithiins and (E)- and (Z)ajoene (Ivanova et al., 2009). Most of these compounds enhance the flavor of investigated culinary herbs (ramson, chives and samardala). In ramson leaves the flavour is more delicate compared to agriculture garlic (Piątkowska et al., 2015), despite of the active sulphur compounds in it that are seven times more than those in garlic (Lachowicz et al., 2017).

Tarragon (Artemisia dracunculos L.) is a medicinal plant from the Asteraceae family (Obolskiy et al., 2011) with significant importance in culinary as a spice (Pripdeevech and Wongpornchai, 2004) and herbal medicine (Pripdeevech and Wongpornchai, 2004; 
Mariutti et al., 2018). French tarragon (also known as 'German tarragon') and Russian tarragon are the two main cultivars. French tarragon has a cool, sweet, liquorice-like aroma with slight bitter tones. Its taste is herbaceous, with anise- and basil-like notes, and it is considered to be more delicate than the Russian tarragon (Obolskiy et al., 2011). Tarragon is an important ingredient in sauces (as Hollandaise, Béarnaise and Tartar sauces), Dijon mustard, Montpellier butter and vinaigrettes (Pripdeevech and Wongpornchai, 2004). It was reported that essential oils, as well as acetone, chloroform, methanol and water extracts of tarragon, possessed well-pronounced antimicrobial activity. Ethanol extracts of A. dracunculus possess antiinflammatory, hepatoprotective activity. The analgesic effect of a French tarragon extract was reported (Obolskiy et al., 2011). Mariutti et al. (2018) established antioxidant activity of ethanol extracts of dried tarragon by DPPH and ABTS methods. Moreover, Rajabian et al. (2017) determine the content of phenols, flavonoids and proanthocyanidins in methanol, dichloromethane, water, n-hexane, ethyl acetate and n-butanol extracts and their antioxidant activity, respectively. In addition, AbdelGawad et al. (2014) evaluated the total phenolic and flavonoid contents, as well as in vitro antioxidant activity, but in the defatted methanolic extracts of six Allium species, growing in Egypt. All these extracts were obtained by some solvents that are restricted for culinary purposes.

Despite the various investigations of different extracts of above mention culinary herbs information about inulin content, sugars and some pigments were absent or slightly studied. Moreover, for culinary purposes, water extracts are mainly used or the dried plant material, not acetone or non-polar solvents as hexane and ethyl acetate. Thus, the present study evaluates bioactive compounds in water extracts of selected culinary herbs.

The object of the current study was to evaluate the content of fructans and antioxidants in the leaves of commercially available four culinary herbs: tarragon (Artemisia dracunculos L.), chives (Allium schoenoprasum), ramson (Allium ursinum L.) and samardala (Nectaroscordum siculum Lindl.) used in Bulgaria for culinary purposes.

\section{Materials and methods}

\subsection{Reagents and standards}

DPPH (1,1-diphenyl-2-picrylhydrazyl radical), TPTZ (2,4,6-tri-(2-pyridyl)-s-triazine), Trolox (6hydroxy-2,5,7,8-tetramethylchroman-2-carboxylic acid), gallic acid, quercetin, Folin-Ciocalteu reagent, 1-kestose, nystose, sucrose, glucose, fructose and methanol were purchased from Sigma-Aldrich (Steinheim, Germany). All reagents were of analytical grade.

\subsection{Plant materials}

All culinary herbs used in this study are commercially available. They were purchased from local markets in Plovdiv. Chives were produced by Kotani. Ramson garlic has been obtained from Decrassin Ltd. (Bulgaria). Tarragon was produced by Bioset Ltd. Batch L1033 (Plovdiv). Samardala salt was consisted of dry samardala leaves mixed with salt and was produced by Mia Foods (Sofia). All culinary herbs were used as they were obtained.

\subsection{Extracts preparation}

Culinary herbs were extracted with distilled $\mathrm{H}_{2} \mathrm{O}$ in solid to liquid ratio 1:10 (w/v). The extraction procedure was performed in an ultrasonic bath (SIEL, Gabrovo, Bulgaria, $35 \mathrm{kHz}$ and $300 \mathrm{~W}$ ) for $20 \mathrm{mins}$, at $75^{\circ} \mathrm{C}$. The obtained extracts were filtered, and the residues were extracted once again under the above mentioned conditions. The combined extracts were used for further analysis.

\subsection{Total chlorophylls and carotenoids}

Total chlorophylls and carotenoids were spectrophotometrically determined in $95 \%$ ethanol extracts at three wavelengths $(664,648$ and $470 \mathrm{~nm})$ and calculated according to Lichtenthaler and Wellburn (1983). The results were presented as $\mu \mathrm{g} / \mathrm{g}$ dry weight (dw).

\subsection{Total phenolic contents}

Total phenolic content was measured using a FolinCiocalteu reagent. Briefly, $1 \mathrm{~mL}$ Folin-Ciocalteu reagent (diluted five times) was mixed with $0.2 \mathrm{~mL}$ culinary herb water extracts and $0.8 \mathrm{~mL} 7.5 \% \mathrm{Na}_{2} \mathrm{CO}_{3}$. The reaction was performed for 20 mins at room temperature in darkness. The absorbance was measured at $765 \mathrm{~nm}$ against the blank, prepared with distilled water. The results were expressed as mg equivalent of gallic acid (GAE) per g dried weight (dw), according to Ivanov et al. (2014).

\subsection{The total flavonoids content}

The total flavonoids content was analysed by $\mathrm{Al}$ $\left(\mathrm{NO}_{3}\right)_{3}$ reagent as previously described (Kivrak et al., 2009). After 40 mins the absorbance was measured at $415 \mathrm{~nm}$ against the blank. The results were presented as mg equivalents quercetin (QE) per g dry weight (dw) according to the calibration curve (Ivanov et al., 2014). 


\subsection{Total caffeic acid derivatives}

The culinary herb water extracts $(1 \mathrm{~mL})$ were mixed with $2 \mathrm{~mL} 0.5 \mathrm{M} \mathrm{HCl}, 2 \mathrm{ml}$ Arnow's reagent, $2 \mathrm{~mL}$ $\mathrm{NaOH}(2.125 \mathrm{M})$ and $3 \mathrm{~mL}$ distilled water. The blank sample was prepared using all the reagents only without Arnow's reagent. The absorbance was measured at 525 nm. Total dihydroxy cinnamic acid content (including caffeoyl derivatives) was presented as $\mathrm{mg}$ chlorogenic acid (CAE) per g dw (Fraisse et al., 2011).

\subsection{The DPPH radical-scavenging ability}

Culinary herb extract $(0.15 \mathrm{~mL})$ was mixed with $2.85 \mathrm{~mL} 0.1 \mathrm{mM}$ solution of DPPH in methanol. The sample was incubated for $15 \mathrm{mins}$ at $37^{\circ} \mathrm{C}$. The reduction of absorbance was measured at $517 \mathrm{~nm}$ in the comparison to the blank containing methanol and \% inhibition was calculated (Ivanov et al., 2014).

\subsection{Ferric reducing antioxidant power (FRAP) assay}

The assay was performed according to Benzie and Strain (1996) with slight modification. The FRAP reagent was freshly prepared by mixing 10 parts $0.3 \mathrm{M}$ acetate buffer (pH 3.6), 1 part $10 \mathrm{mM} \mathrm{2,4,6-} \mathrm{tripyridyl-s-}$ triazine (TPTZ) in $40 \mathrm{mM} \mathrm{HCl}$ and 1 part $20 \mathrm{mM}$ $\mathrm{FeCl}_{3} \times 6 \mathrm{H}_{2} \mathrm{O}$ in distilled $\mathrm{H}_{2} \mathrm{O}$. FRAP $(3.0 \mathrm{ml})$ reagent was mixed with $0.1 \mathrm{~mL}$ culinary herbs water extract. After 10 mins at $37^{\circ} \mathrm{C}$ in darkness, the absorbance was measured at $593 \mathrm{~nm}$ against blank prepared with water. Antioxidant activity was expressed as $\mathrm{mM}$ Trolox ${ }^{\circledR}$ equivalents (TE) per g dry weight (dw) (Ivanov et al., 2014).

\subsection{Analysis of total fructans}

The fructans content was determined spectrophotometrically by resorcinol-thiourea reagent. The hundred microliters water extract was mixed with $0.1 \mathrm{~mL}$ resorcinol ( $1 \%$ solution in $95 \%$ ethanol), $0.1 \mathrm{~mL}$ thiourea $(0.1 \%$ ethanol solution $), 0.8 \mathrm{~mL} 95 \%$ ethanol and $0.9 \mathrm{~mL}$ concentrated $\mathrm{HCl}$, heated for 8 mins at $80^{\circ} \mathrm{C}$, cooled at $25^{\circ} \mathrm{C}$ and filled with water until $10 \mathrm{~mL}$. Then the absorbance was measured at $480 \mathrm{~nm}$ against a blank sample prepared with distilled water (Petkova et al., 2017).

\subsection{HPLC-RID analysis of inulin and sugars}

Chromatographic separations and determination of presented inulin and sugars were performed on an HPLC instrument Elite Chrome Hitachi (Japan), coupled with refractive index detector (RID) Chromaster 5450 operating at $35^{\circ} \mathrm{C}$. The separation was done with mobile phase distilled $\mathrm{H}_{2} \mathrm{O}$ on a column Shodex ${ }^{\circledR}$ Sugar SP0810 (300 $\mathrm{mm} \times 8.0 \mathrm{~mm}$ i.d.) with $\mathrm{Pb}^{2+}$ and a guard column Shodex SP - G $(5 \mu \mathrm{m}, 6 \times 50 \mathrm{~mm})$ at $85^{\circ} \mathrm{C}$, with a flow rate $1.0 \mathrm{~mL} / \mathrm{min}$ and the injection volume $20 \mu \mathrm{L}$ (Petkova et al., 2014).

\subsection{Statistical analysis}

All analyses were performed in triplicate $(n=3)$ and replicated at least twice. The results were calculated as mean values \pm standard deviation using Excel (Microsoft Inc., USA).

\section{Results and discussion}

\subsection{Total chlorophylls and carotenoids}

In many cases, the quality of culinary herbs depends on the preservation of the green colour of dried herbs. Additionally, in leaves of plants, many carotenoids were also accumulated, and their amount is also important as compounds with antioxidant effect. However, there is very limited information in the literature regarding the content of carotenoids from commonly consumed herbs. Therefore, the content of natural pigments as carotenoids and chlorophylls is important to be evaluated.

The content of total chlorophylls and carotenoids were summarized (Table 2). From the obtained results chives leaves demonstrated the highest values of total chlorophylls $2255.5 \mu \mathrm{g} / \mathrm{g} \mathrm{dw}$. The content of total chlorophylls in leaves of culinary herbs lowered in the following order: chives $>$ ramson $>$ tarragon $>$ samardala. In the current study, carotenoids were only found in tarragon leaves in minor amounts $(9.4 \pm 1.1 \mu \mathrm{g} / \mathrm{g} \mathrm{dw})$. Moreover, chives leaves seem to be relatively abundant in pigments in comparison to other studied Allium plants. However, our reports for total chlorophylls in chives leaves were higher than $1.2 \mathrm{mg} / \mathrm{g} \mathrm{dw}$ (Viña and Cerimele, 2009). Only, Egert and Tevini (2002) found higher total chlorophylls in chives leaves $(6.7 \mathrm{mg} / \mathrm{g} \mathrm{dw})$. Moreover, this is the first study that evaluated the content of chlorophylls in commercially available samardala (Nectaroscordum siculum Lindl.) mixed with salt. The obtained results for chlorophyll (a) and chlorophyll (b) in ramsons leaves were higher than the

Table 2. Concentrations of total chlorophylls and total carotenoids in $95 \%$ ethanol extract from culinary herbs $\mu \mathrm{g} / \mathrm{g} \mathrm{dw}$

\begin{tabular}{lccccc}
\hline \multicolumn{1}{c}{ Sample } & Chlorophyll (a) & Chlorophyll (b) & Chlorophyll (a+b) & Total carotenoids \\
\hline Chives (Allium schoenoprasum L.) & $1043.5 \pm 0.5$ & $1048.5 \pm 0.3$ & $2255.5 \pm 0.5$ & Not detected \\
Ramson (Allium ursinum L.) & $777.2 \pm 1.2$ & $311.1 \pm 2.3$ & $1088.3 \pm 1.2$ & Not detected \\
$\begin{array}{l}\text { Samardala (Nectaroscordum } \\
\text { Lindl.) }\end{array}$ & siculum & $106.2 \pm 2.2$ & $46.2 \pm 0.2$ & $152.3 \pm 0.4$ & Not detected \\
Tarragon (Artemisia dracunculus L.) & $74.1 \pm 0.2$ & $284.9 \pm 1.8$ & $359.1 \pm 1.1$ & $9.4 \pm 1.1$ \\
\hline
\end{tabular}


reported values (Štajner et al., 2008; Manukyan et al., 2017). However, the content of carotenoids is too low to be detected, due to the sensitivity of the used method. In another study, Štajner and Varga (2003) reported higher than our results for natural pigment in ramson leaves $(2.87 \pm 0.03 \mathrm{mg} / \mathrm{g}$ of chlorophyll (a), $1.35 \pm 0.01 \mathrm{mg} / \mathrm{g}$ of chlorophyll (b), and $9.99 \pm 0.01 \mathrm{mg} / \mathrm{g}$ of carotenoids, respectively). In addition, detected total carotenoids in Artemisia dracunculus L. were lower than the report of Daly et al. (2010) who reported $11.1 \mathrm{mg} / 100 \mathrm{~g}$ of culinary herbs. These differences in comparison with our results could be explained with harvest time and storage conditions.

\subsection{Total phenolic compounds}

The values of total phenol, total flavonoids, caffeic acid derivatives, as well as antioxidant activity of culinary herbs were summarized (Table 3 ). The highest values of total phenolic content were found in tarragon leaves ( $25 \mathrm{mg} \mathrm{GAE} / \mathrm{g} \mathrm{dw}$ ), followed by ramson leaves (16.91 mg GAE/g dw). Caffeic acid derivatives were detected only in tarragon leaves. Contrary to the lowest levels of total phenols (only $0.77 \mathrm{mg} \mathrm{GAE} / \mathrm{g}$ ) in samardala sample, only in them were detected the highest content of total flavonoids (7.87 mg QE/g dw).

Total phenols in chives leaves were higher than reports of Zheng and Wang (2001) (1.5 mg GAE/g fw). Some Bulgarian authors (Alexieva et al., 2013; Popova et al., 2014a, 2014b) reported that total phenolic contents in microwave extracts, infusions and decoction from samardala ( 0.20 to $0.6 \mathrm{mg} \mathrm{GAE} / \mathrm{g}$ fresh weight and from 9.1 to $22.9 \mathrm{mg} \mathrm{GAE} / \mathrm{g}$ dry leaves, respectively). However, they used pure leaves, not mixed with salt, as typically consumed as a culinary herb. Therefore, this explained the obtained by us result for total phenolic content in samardala (leaves, ground with salt) $-0.77 \mathrm{mg}$ $\mathrm{GAE} / \mathrm{g} \mathrm{dw}$.

However, our finding for Bulgarian ramson leaves was in agreement with Sapunjieva et al. (2012) - $16 \mathrm{mg}$ $\mathrm{GAE} / \mathrm{g} \mathrm{dw}$, close to some values of leaf extracts of Allium ursinum L. from Montenegro and Bosnia and Herzegovina - 1305.55 to $1833.33 \mathrm{mg} \mathrm{GAE} / 100 \mathrm{~g}$ DW (Pejatović et al., 2017). Our results were higher than those reported by Piątkowska et al. (2015) Polish ramson and more than two times higher than average amounted to $713.7 \mathrm{mg} / 100 \mathrm{~g} \mathrm{dw}$ of ramson leaves in three different ecotypes (Błażewicz-Woźniak and Michowska, 2011).

The total flavonoids content in ramson was $5.31 \mathrm{mg}$ QE/g dw. Our results were close Allium ursinum L. to ecotype Gornje Lipovo (2.50 to $6.87 \mathrm{mg}$ QE/g DW) (Piątkowska et al., 2015), higher than $3.24 \mathrm{mg} / \mathrm{g}$ dw reported by Djurdjević et al. (2004) and BłażewiczWoźniak and Michowska (2011). However, in our water eISSN: 2550-2166 extracts DCA, expressed as caffeic acid equivalents were not found. In some reports, their content reached to 788.2 mg/100 g dw (Błażewicz-Woźniak and Michowska, 2011).

\subsection{Antioxidant activity}

The antioxidant activity of culinary herbs was evaluated by two methods (Shannon et al., 2018), based on different mechanisms (Table 3). The highest value of antioxidant activity was demonstrated by tarragon leaves $102.88 \pm 0.10 \mathrm{mM} \quad \mathrm{TE} / \mathrm{g} \quad \mathrm{dw}$ (DPPH assay) and $175.00 \pm 0.50 \mathrm{mM}$ TE/g dw (FRAP assay). From Allium genus chives and ramson, two representatives showed close radical scavenging activity -11.25 and $10.10 \mathrm{mM}$ $\mathrm{TE} / \mathrm{g} \mathrm{dw}$. The lowest antioxidant activity was evaluated for samardala leaves $2.19 \pm 0.20 \mathrm{mM} \mathrm{TE} / \mathrm{g} \mathrm{dw}$ (DPPH method) and $0.08 \pm 0.01 \mathrm{mM} \mathrm{TE} / \mathrm{g}$ dw (FRAP assay). A more recent study found that extract of the leaves of $A$. ursinum L. had a strong antioxidant activity, especially due to the high content of flavonoids (Pejatović et al., 2017). Stajner et al. (2004) have found that leaves have the highest antioxidant activity in comparison with bulbs and stalks because of the high activity of enzymes related to the antioxidant system and the high levels of antioxidants. However, our DPPH antioxidant activity was higher than reported values from Bulgarian plants $9.94 \mu \mathrm{g} \mathrm{TE} / \mathrm{g}$ (Sapunjieva et al., 2012). Stanciu et al. (2017) also evaluated the total phenols and antioxidant capacity of ethanol extracts of dried tarragon. Our results for tarragon were higher than those of Rajabian et al. (2016) for water fraction total phenols (9.3 tannic acid equivalent) and total flavonoids - $1.6 \mathrm{QE} / \mathrm{g} \mathrm{dw}$. However, our data were in accordance with Behbahani et al. (2017) - $24 \mathrm{mg} \mathrm{GAE} / \mathrm{g} \mathrm{dw}$, but our total flavonoids were lower than $20 \mathrm{mg}$ QE/g dw. In addition, our values for total phenols were higher in ramson and chives than reported values by Lenková et al. (2016).

\subsection{Fructan and sugar composition}

The carbohydrate composition of investigated culinary herbs was presented (Table 4). Most of the studies reported values for fructooligosaccharides and inulin in the bulb of Allium representatives (Van Loo et al., 1995; Jovanovic-Malinovska et al., 2014). It was found that carbohydrates in Alliums bulbs account for a major portion (from 65 to $80 \%$ of the dry weight). The main constituent of the non-structural carbohydrates is fructose, glucose, sucrose and a series of fructooligosaccharides (fructosyl polymers) with different degrees of polymerization (DP) in most of the cases around 12 (Benkeblia and Shiomi, 2006). A medium level of fructooligosaccharides in bulbs of scallion, onion, garlic, leek, spring garlic varied from $0.51 \pm 0.019$ to $0.84 \pm 0.023 \mathrm{~g} / 100 \mathrm{~g} \mathrm{dw}$ (Jovanovic- 
Table 3. Total phenolic content, total flavonoids, caffeic acid derivatives (DCA) and antioxidant activity

\begin{tabular}{lcccccc}
\hline Sample & $\begin{array}{c}\text { Total phenolic content, } \\
\text { mg GAE/g dw }\end{array}$ & $\begin{array}{c}\text { Total flavonoids, } \\
\text { mg QE/g dw }\end{array}$ & DCA, mg CAE/g dw & \multicolumn{2}{c}{ Antioxidant activity, mM TE/g dw } \\
\cline { 5 - 7 } Chives & $6.93 \pm 0.15$ & $0.98 \pm 0.15$ & Not detected & $11.25 \pm 0.50$ & $5.40 \pm 1.93$ \\
Ramson & $16.91 \pm 0.5$ & $5.31 \pm 0.20$ & Not detected & $10.10 \pm 0.10$ & $42.11 \pm 0.50$ \\
Samardala & $0.77 \pm 0.15$ & $7.87 \pm 0.20$ & Not detected & $2.19 \pm 0.20$ & $0.08 \pm 0.01$ \\
Tarragon & $25.00 \pm 0.15$ & $6.46 \pm 0.15$ & $13.52 \pm 0.50$ & $102.88 \pm 0.10$ & $175.00 \pm 0.50$ \\
\hline
\end{tabular}

Table 4. Total fructans, inulin and sugars content in culinary herbs, g/100 g dw

\begin{tabular}{lccccccc}
\hline Plant & Total fructans & Inulin & Nystose & 1-Kestose & Sucrose & Glucose & Fructose \\
\hline Chives & $5.66 \pm 0.05$ & Traces & Absent & $3.86 \pm 0.25$ & Absent & $4.84 \pm 0.05$ & $2.53 \pm 0.01$ \\
Ramson & $2.20 \pm 0.31$ & $0.60 \pm 0.20$ & $0.35 \pm 0.11$ & $0.40 \pm 0.11$ & $0.70 \pm 0.20$ & Absent & $0.71 \pm 0.11$ \\
Samardala & $2.31 \pm 0.48$ & Traces & Absent & Absent & Absent & $2.18 \pm 0.08$ & $3.29 \pm 0.11$ \\
Tarragon & $0.58 \pm 0.01$ & $0.41 \pm 0.05$ & Absent & $0.98 \pm 0.05$ & Absent & $0.33 \pm 0.02$ & $0.94 \pm 0.10$ \\
\hline
\end{tabular}

Malinovska et al., 2014). To the best of our knowledge, this is the first detailed study that evaluated the content of fructooligosaccharides and inulin in the leaves of these spices. Fructan content in chives (Allium schoenoprasum L.) leaves was mainly due to the presence of 1-kestose $(3.86 \pm 0.25 \mathrm{~g} / 100 \mathrm{dw})$. However, in ramson leaves (Allium ursinum L.) inulin, nystose and 1-kestose were detected, but their content did not high $0.60 \mathrm{~g} / 100 \mathrm{dw}$. Inulin and 1-kestose were also detected in tarragon leaves. In general, fructose was found in all investigated culinary herbs, as its content in samardala and chives was higher than other herbs. Sucrose was found only in ramson leaves. Glucose was dominating sugar in chives, but absolutely absent in ramson. The detected content of 1-kestose as the main representatives from fructooligosaccharides in chives and ramson leaves was higher than reported values for fructooligosaccharides (DP 3-5) in Chinese chive and leek $(0.1$ to $0.9 \mathrm{mg} / \mathrm{g}$ fresh weight) (Benkeblia and Shiomi, 2006). Our values were comparable with fructooligosaccharides content for dry weight in Thai foods as leek and Chinese chive (Allium chinense G. Don) (Judprasong et al., 2011). In addition, Campbell et al. (1997) also detected $0.11 \mathrm{~g} / 100 \mathrm{~g}$ fructooligosaccharides in Chinese chives. Judprasong et al. (2011) reported for the presence of fructooligosaccharides, fructose, glucose and sucrose in spice garlic, great-headed (Allium ampeloplasum Linn) $1.63,0.15,0.14$ and $1.14 \mathrm{~g} / 100 \mathrm{~g}$, respectively. In the current study, sucrose was not detected in chives leaves. The levels of fructose and oligofructoses in leaves of other representatives of Allium, as onion drooping (Allium nutans L.) and wild leek or onion winning (Allium victorialis L.) reached 15.5 and $9.3 \% \mathrm{dw}$, while polyfructans in them were 2.2 and $1.8 \% \mathrm{dw}$, respectively (Bagaoutdinova et al., 2001). In our case, the content of fructose and fructooligosaccharides lowed in the following order chives $>$ samardala $>$ tarragon $>$ ramson, as their sum did not exceed $7 \mathrm{~g} / 100 \mathrm{~g} \mathrm{dw}$.

\section{Conclusion}

The current study evaluated the content of biologically active substances and antioxidant potential of some plants used in culinary purpose. From the investigated culinary herbs, tarragon demonstrated the highest antioxidant activity, followed by ramson. The highest levels of total carotenoids and caffeic acid derivatives were found only in tarragon leaves. Chives, ramson and tarragon leaves were evaluated as sources of prebiotics as 1-kestose, nystose and inulin. The current investigation enriches the information about these edible plants used in human nutrition and demonstrates their health beneficial properties.

\section{Conflict of Interest}

The authors declare no conflict of interest.

\section{References}

Abdel-Gawad, M., Abdel-Aziz, M., El-Sayed, M., ElWakil, E. and Abdel-Lateef, E. (2014). In vitro antioxidant, total phenolic and flavonoid contents of six Allium species growing in Egypt. Journal of Microbiology, Biotechnology and Food Sciences, 3 (4), 343-346.

Alexieva, I., Mihaylova D. and Popova, A. (2013). Evaluation of the antioxidant capacity of aqueous extracts of fresh samardala (Allium bulgaricum L.) leaves. Food Science, Engineering and Technology 2013, 18-19 October 2013. Scientific Works, LX, 826- 831 .

Alexieva, J., Mihaylova, D. and Popova, A. (2014). Antioxidant capacity and thin layer chromatography of ethanol extracts of Allium ursinum L. and Allium bulgaricum L. Scientific Bulletin. Series F. Biotechnologies, XVIII, 91-96.

Bagaoutdinova, I., Fedoseyeva, P. and Okoneshnikova, F. (2001). Fructose-containing carbohydrates in plants of different families localization and content. Chemistry and computational simulation. Butlerov 
Communications, 2(5),13-16.

Behbahani, B., Shahidi, F., Yazdi, F., Mortazavi, S. and Mohebbi, M. (2017). Antioxidant activity and antimicrobial effect of tarragon (Artemisia dracunculus) extract and chemical composition of its essential oil. Journal of Food Measurement and Characterization, 11(2), 847-863. https:// doi.org/10.1007/s11694-016-9456-3

Benkeblia, N. and Shiomi, N. (2006) Fructooligosaccharides of edible alliums: occurrence, chemistry and health benefits.Current Nutrition and Food Science, 2(2), 181-191. https:// doi.org/10.2174/157340106776818808

Benzie, I. and Strain, J. (1996). The Ferric Reducing Ability of Plasma (FRAP) as a measure of antioxidant power: The FRAP assay. Analytical Biochemistry, 239(1), 70-76. https:// doi.org/10.1006/abio.1996.0292

Błażewicz-Woźniak, M. and Michowska, A. (2011). The growth, flowering and chemical composition of leaves of three ecotypes of Allium ursinum L. Acta Agrobotanica, 64(4), 171-180. https:// doi.org/10.5586/aa.2011.058

Campbell, J.M., Bauer, L.L., Fahey Jr., G.C., Hogarth, A.J.C.L., Wolf, B.W. and Hunter, D.E. (1997). selected fructo-oligosaccharide (1-kestose, nystose, and 1f-b-fructofuranosylnystose) composition of foods and feeds. Journal of Agricultural and Food Chemistry, 45, 3076-3082. https://doi.org/10.1021/ jf970087g

Daly, T., Jiwan, M.A, O’brien, N.M. and Ahern, S.A. (2010). The carotenoid content of commonly consumed herbs and assessment of their bioaccessibility using an in vitro digestion model. Plant Foods for Human Nutrition, 65, 164-169. https://doi.org/10.1007/s11130-010-0167-3

Djurdjević, L., Dinić, A., Pavlović, P., Mitrović, M., Karadzić, B. and Tesević, V. (2004). Allelopathic potential of Allium ursinum L. Biochemical Systematics and Ecology, 32(6), 533-544. https:// doi.org/10.1016/j.bse.2003.10.001

Egert, M. and Tevini, M. (2002). Influence of drought on some physiological parameters symptomatic for oxidative stress in leaves of chives (Allium schoenoprasum). Environmental and Experimental Botany, 48, 43-49. https://doi.org/10.1016/S00988472(02)00008-4

ESA (European Spice Association). (2018). List of Culinary Herbs and Spices, p. 1-5. Europe: ESA

Fraisse, D., Felgines, C., Texier, O. and Lamaison, J.-L. (2011). Caffeoyl derivatives: major antioxidant compounds of some wild herbs of the Asteraceae family. Food and Nutrition Sciences, 2, 181-192. https://doi.org/10.4236/fns.2011.230025

Grzeszczuk, M., Wesolowska, A., Jadczak, D. and Jakubowska, B. (2011). Nutritional value of chives edible flowers. Acta Scientiarum Polonorum Hortorum Cultus, 10(2), 85-94.

Haro, G., Sinaga, S.M., Iksen, I., Nerdy, N. and Theerachetmongkol, S. (2017). Protective effects of chives leaves (Allium schoenoprasum L.) infusion against ethylene glycol and ammonium chloride induced nephrolithiasis in rats. Journal of Applied Pharmaceutical Science, 7(08), 222-225.

Ivanov, I., Vrancheva, R., Marchev, A., Petkova, N., Aneva, I., Denev, P., Georgiev, V. and Pavlov, A. (2014). Antioxidant activities and phenolic compounds in Bulgarian Fumaria species. International Journal of Current Microbiology and Applied Sciences, 3(2), 296-306.

Ivanova, A., Mikhova, B., Najdenski, H., Tsvetkova, I. and Kostova, I. (2009). Chemical composition and antimicrobial activity of wild garlic Allium ursinum of Bulgarian origin. Natural Product Communications, 4(8), 1059-1062.

Jovanovic-Malinovska, R., Kuzmanova, S. and Winkelhausen, E. (2014). Oligosaccharide profile in fruits and vegetables as sources of prebiotics and functional foods. International Journal of Food Properties, 17(5), 949-965. https:// doi.org/10.1080/10942912.2012.680221

Judprasong, K., Tanjor, S., Puwastien, P. and Sungpuag, P. (2011) Investigation of Thai plants for potential sources of inulin-type fructans. Journal of Food Composition and Analysis, 24, 642-649. https:// doi.org/10.1016/j.jfca.2010.12.001

Kivrak, I., Duru, M., Öztürk, M., Mercan, N., Harmandar, M. and Topçu, G. (2009). Antioxidant, anticholinesterase and antimicrobial constituents from the essential oil and ethanol extract of Salvia potentillifolia. Food Chemistry, 116(2), 470-479. https://doi.org/10.1016/j.foodchem.2009.02.069

Kmiecik, W. and Lisiewska, Z. (1999). Effect of pretreatment and conditions and period of storage on some quality indices of frozen chive (Allium schoenoprasum L.). Food Chemistry, 67, 61-66. https://doi.org/10.1016/S0308-8146(99)00111-9

Lachowicz, S., Kolniak-Ostek, J., Oszmianski, J. and Wisniewski, R. (2017). Comparison of phenolic content and antioxidant capacity of bear garlic (Allium ursinum L.) in different maturity stages. Journal of Food Processing and Preservation, 41(1), 1-10. https://doi.org/10.1111/jfpp.12921

Lenková, M., Bystrická, J., Tóth T. and Hrstková, M. 
(2016). Evaluation and comparison of the content of total polyphenols and antioxidant activity of selected species of the genus Allium, Journal of Central European Agriculture, 17(4), 1119-1133. https:// doi.org/10.5513/JCEA01/17.4.1820

Lichtenthaler, H.K. and Wellburn, A.R. (1983). Determination of total carotenoids and chlorophylls $\mathrm{a}$ and $\mathrm{b}$ of leaf in different solvents. Biochemical Society Transactions, 11(5), 591-592. https:// doi.org/10.1042/bst0110591

Manukyan, K.A., Ayrapetova, A.Y. and Shatalova, T.A. (2017). Preparation and investigation of antioxidant activity of extracts from leaves of Allium ursinum L. and Allium victoralis L. The Journal of Scientific Articles "Health and Education Millennium", 19(3), 150-153. https://doi.org/10.26787/nydha-2226-74252017-19-3-150-153

Mariutti, L.R B., Barreto, G.P.D.M., Bragagnolo, N. and Mercadante, A.A.Z. (2008). Free radical scavenging activity of ethanolic extracts from herbs and spices commercialized in Brazil. Brazilian Archives of Biology and Technology, 51(6), 1225-1232. https:// doi.org/10.1590/S1516-89132008000600018

Mathew, B. (1996). A review of Allium section Allium: Royal Botanic Gardens, Kew Publishing UK: Richmond, Surrey

Obolskiy, D., Pischel, I., Feistel, B., Glotov, N. and Heinrich, M. (2011). Artemisia dracunculus L. (tarragon): a critical review of its traditional use, chemical composition, pharmacology, and safety. Journal of Agriculture and Food Chemistry, 59(21), 11367-11384. https://doi.org/10.1021/jf202277w

Pejatović, T., Samardžić, D. and Krivokapić, S. (2017). Antioxidative properties of a traditional tincture and several leaf extracts of Allium ursinum L. (collected in Montenegro and Bosnia and Herzegovina). Journal of Materials and Environmental Sciences, 8 (6), 1929-1934.

Petkova, N., Vrancheva, R., Denev, P., Ivanov, I. and Pavlov, A. (2014). HPLC-RID method for determination of inulin and fructooligosacharides, Acta Scientifica Naturalis, 1:99-107.

Petkova, N., Ivanova, L., Filova, G., Ivanov, I. and Denev, P. (2017). Antioxidants and carbohydrate content in infusions and microwave extracts from eight medicinal plants, Journal of Applied Pharmaceutical Science, 7(10), 055-061.

Phillips, R. and Rix, M. (1998). Conservatory and indoor plants: Vol. 1. London, UK: Pan Macmillan.

Piątkowska, E., Kopeć, A. and Leszczyńska, T. (2015). Basic chemical composition, content of micro and macroelements and antioxidant activity of different varieties of garlic's leaves polish origin. Żywność. Nauka. Technologia. Jakość, 1, 181- 192.

Popova, A., Mihaylova, D. and Alexieva, J. (2014a). Study on the antioxidant activity of dried Allium bulgaricum leaves. Proceedings. Biotechnologies and Food Technologies, Vol. 53., p. 27-31. Bulgaria: University of Ruse

Popova, A., Mihaylova, D. and Alexieva, I. (2014b). Comparative study on the antioxidant activity of selected culinary plants growing in Bulgaria. International Journal of Current Microbiology and Applied Sciences, 3(11), 436-444.

Pripdeevech, P. and Wongpornchai, S. (2012). Series in Food Science, Technology and Nutrition. In Peter K. (Ed.) Handbook of Herbs and Spices. $2^{\text {nd }}$ ed., p. 583600. Elsevier: Woodhead Publishing.

Rajabian, A, Khayyat, M.H., Emami, S.A., TayaraniNajaran, Z., Oskooie, R.R. and Asili, J. (2017). Phytochemical evaluation and antioxidant activity of essential oil, and aqueous and organic extracts of Artemisia dracunculus. Jundishapur Journal of Natural Pharmaceutical Product. 12(1), e32325. https://doi.org/10.5812/jjnpp.32325

Sapunjieva, T., Alexieva, I., Mihaylova, D. and Popova, A. (2012). Antimicrobial and antioxidant activity of extracts of Allium ursinum L. Journal of BioScience and Biotechnology, SE/ONLINE, 143-145.

Shannon, E., Jaiswal, A.K. and Abu-Ghannam, N. (2018). Polyphenolic content and antioxidant capacity of white, green, black, and herbal teas: a kinetic study. Food Research, 2(1), 1 - 11. http:// doi.org/10.26656/fr.2017.2(1).117

Štajner, D. and Varga, I.S. (2003). An evaluation of the antioxidant abilities of Allium species. Acta Biologica Szegediensis, 47(1-4), 103-106.

Štajner, D., Čanadanović-Brunet, J. and Pavlović, A. (2004). Allium schoenoprasum L., as a natural antioxidant. Phytotherapy Research, 18(7), 522-524. https://doi.org/10.1002/ptr.1472

Štajner, D., Popović M.B., Čanadanović-Brunet, J. and Štajner, M. (2008). Antioxidant and scavenger activities of Allium ursinum. Fitoterapia, 79(4), 303305. https://doi.org/10.1016/j.fitote.2007.01.008

Stanciu, G., Cristache, N., Lupsor, S. and Dobrinas, S. (2017). Evaluation of antioxidant activity and total phenols content in selected spices. Revista de Chimie (Bucharest), 68(7), 1429-1434.

Tomšik, A., Šarić, L., Bertoni, S., Protti, M., Albertini, B., Mercolini, L. and Passerini, N. (2018). Encapsulations of wild garlic (Allium ursinum L.) extract using spray congealing technology. Food 
Research International [In press]. https:// doi.org/10.1016/j.foodres.2018.10.081

Van Loo, J., Coussement, P., Leenheer, L.D., Hoebregs, H. and Smits, G. (1995). On the presence of inulin and oligofructose as natural ingredients in the western diet. Critical Reviews in Food Science, 35, 525-552. https:// doi.org/10.1080/10408399509527714

Viña, S.Z. and Cerimele, E.L. (2009). Quality changes in fresh chives (Allium schoenoprasum L.) during refrigerated storage. Journal of Food Quality, 32, 747-759. https://doi.org/10.1111/j.17454557.2009.00281.x

Vlase, L., Parvu, M., Parvu, E.A. and Toiu, A. (2013). Chemical constituents of three Allium species from Romania. Molecules, 18, 114-127. https:// doi.org/10.3390/molecules 18010114

Zheng, W. and Wang, S.Y. (2001). Antioxidant activity and phenolic compounds in selected herbs. Journal of Agriculture and Food Chemistry, 49(11), 51655170. https://doi.org/10.1021/jf010697n 